\title{
Effect of Vertical Oscillatory Pressure on Pain Intensity and Respiratory Variables in Patients with Cervical Spondylosis
}

\author{
Article by Ilesanmi Oluwafemi Temitayo ${ }^{1}$, Egwu M.O, Adedoyin R.A ${ }^{2}$ \& Esan $\mathrm{O}^{3}$ \\ ${ }^{1}$ Ph.D. in Public Health, Texila American University, Department of Physiotherapy, \\ Nigeria \\ ${ }^{2}$ Department of Medical Rehabilitation, College of Health Sciences, Obafemi \\ Awolowo University, Nigeria \\ ${ }^{3}$ Department of Orthopaedic Surgery and Traumatology, College of Health Sciences, \\ Obafemi Awolowo University, Nigeria \\ E-mail: aboundinggrace08@yahoo.com
}

\begin{abstract}
Vertical Oscillatory Pressure (VOP) is the simplest and effective manual therapy technique employed by physical therapists for the treatment of cervical spondylosis (CS). However, its effect on the respiratory system has not been established. Therefore this study is assessing the effect of VOP on pain intensity and respiratory variables of patients with cervical spondylosis. The study determined and compared the pain intensity, respiratory rate and vital capacity during and after the application of vertical oscillatory pressure (VOP) in patients with cervical spondylosis. Sixty participants (30 patients, 30 controls) aged between 27-77 years (mean 48.50 $\pm 13.41,48.03 \pm 13.74$ ) and comprising 26 males and 34 females, after giving informed consent, were recruited for the study. The respiratory rate, vital capacity and pain intensity were measured before, during and one minute after application of VOP. The results showed there were no significant differences in the respiratory rates for the subjects $(F=0.13, p>0.05)$, while vital capacity significantly increased only in the subject groups after VOP, $(F=3.20, p<0.05)$. Furthermore, VOP significantly reduced pain intensity of the subjects with cervical spondylosis $(F=30.59, p<0.05)$. It was concluded that there was a strong association between the hypoalgesic effect of VOP and the sympatho-excitatory response which cuts across the respiratory functions of patients with cervical spondylosis involving respiratory rate and vital capacity.
\end{abstract}

Keywords: Vertical Oscillatory Pressure (VOP), Pain Intensity, Respiratory Variables

\section{Introduction}

Cervical spondylosis or cervical osteoarthritis is a progressive degeneration of the intervertebral disc in the cervical region leading to changes in the surrounding structures especially the bones and the ligaments. It has characteristics of bony outgrowths, nerve root compression, paraesthesia, pain and/or muscle weakness (Ojoawo et al, 2016). It is noted that the degenerative changes in the joints lead to inflammation and collagen deposits on soft tissues in and around subsequently causing muscle spasm, reduced electrical activities in the nerves and loss of function in the spine and/or muscles (Egwu, et al, 2012).

Subjects seeking medical help for this condition primarily complain of pain and/or stiffness when bending the neck forward or backward during activity (Corwell, 2013). It is known that pain which is of mechanical origin is produced by movement and neck pain in cervical spondylosis often occurs in combination with limited movement and poorly defined neurological symptoms affecting the upper limbs (Karnath, 2012). Most spinal movements take place at the neck (between 5th and 7th cervical vertebrae) and these sites account for over 70\% of reported cases of pain of the spine (Ohlendorf et al, 2017).

The incidence of pain at the spine is widely published and more people are seeking medical help for the pain than ever before (Briggs et al, 2009). A clinical standards advisory group report (Salisbury et al, 2013) stated that in U.K. there are 5 million consultations for general 
practice (GPs) for the pain each year. Clinical experience research reports and anecdotal observations show that the trend is similar in some parts of Africa (Egwu et al, 2012) and America (Corwell, 2013). Neck pain is endemic in workers throughout the industrialized world. About two thirds of people will experience neck pain at some time. Prevalence is highest in middle age, with women being affected more than men. The prevalence of neck pain varies widely between studies, with a mean point prevalence of $14.4 \%$ (range 0.4 41.5\%) and mean lifetime prevalence of 23.1\% (range 0.4- 86.8\%) (Hoy et al, 2010).

The treatments among orthodox health care professionals include chemotherapy, surgery and physical therapy In physical therapy, conventional therapeutic modalities include cryotherapy, thermal therapy, massage, exercise, ultrasound, transcutaneous electrical nerve stimulation (Henderson et al, 2013). However, researchers and clinicians differ in their schools of thought on causes of back pain and the therapeutic treatment modalities to be chosen (Egwu et al, 2012). They chose strengthening exercises and spinal manual therapy (SMT) as current therapeutic modalities which have been documented to be of greater effectiveness (Egwu et al, 2012).The oscillatory techniques are gentle forms of manipulation and include vertical oscillatory pressure (VOP), transverse oscillatory pressure (TOP) etc (Ojoawo et al, 2016). 75\% of candidates for manipulation can be helped with the SMT techniques especially VOP which is the simplest and most versatile (Egwu et al, 2012).

Pain may be defined as an unpleasant sensory and emotional experience associated with actual or potential spinal tissue damage or perceived as such (IASP, 2017). Respiratory rate is the number of breath per minute ( $\mathrm{O}^{\prime}$ Leary et al, 2015). Vital capacity is the maximum volume of air that can be forcefully expired into a spirometer after a maximal inspiration (Azevedo et al, 2012). Many studies have examined the effects of VOP on pain intensity of patients with cervical spondylosis (Ojoawo et al, 2016; Ojoawo et al, 2013). However, studies on the effect of VOP, a technique of spinal manual therapy on respiratory parameters of patients with cervical spondylosis are scarce. This study was designed to assess the effects of VOP on pain intensity and respiratory variables (respiratory rate and vital capacity) of subjects with cervical spondylosis.

\section{Significance of study}

The study will provide the physical therapists with baseline data upon which intervention can be based when treating patients with cervical spondylosis coexisting with respiratory problems.

\section{Statement of problem}

Vertical oscillatory pressure is a manipulative procedure that has been documented to be the simplest and most versatile for the treatment of patients with cervical spondylosis (CS). However, its effect on the respiratory system has not been adequately established. This information is necessary as they will be helpful for patients with cervical spondylosis predicting link between documented significant effect of VOP on pain intensity and respiratory functions of patients with cervical spondylosis. This study sought to investigate the effect of VOP on pain intensity and some respiratory variables of patients with cervical spondylosis.

\section{Research objectives}

(1) To determine the pain intensity, respiratory rate and vital capacity before, during and after VOP in patients with cervical spondylosis.

(2) To compare the pain intensity, respiratory rate and vital capacity scores during VOP with the scores before and after VOP in patients with cervical spondylosis.

\section{Hypotheses}

1. $\mathrm{H}_{0}$ : VOP will have no significant effects on vital capacity and respiratory rate of subjects with cervical spondylosis. 
2. $\mathrm{H}_{0}$ : VOP will have no significant effect on pain intensity of subjects with cervical spondylosis.

\section{Inclusion criteria}

The subjects tested must be those who have been diagnosed as having cervical spondylosis, who are symptomatic with neck pain, are referred to the Department of Physiotherapy, Obafemi Awolowo University Teaching Hospitals Complex, Ile-Ife and Wesley Guild Hospital, Ilesa, Osun State and have not been diagnosed with other associated medical conditions which are contraindicated to the treatment technique (VOP) e.g. Cancer of the spine, Cervical cord Myelopathy.

\section{Exclusion criteria}

Patients who have been diagnosed with cervical spondylosis but do not show willingness to participate in the research and patients who cannot tolerate the effect/ pressure of the thumbs on them during the application of vertical oscillatory pressure were excluded from the study.

\section{Literature review}

Vertical oscillatory pressure has been found to reduce pain and improve gross spinal mobility (Shum et al, 2012; Powers et al, 2008). It has been observed that VOP decreases pain intensity scores in low back pain and neck pain subjects without gender or age group bias (Egwu et al, 2012). Vertical oscillatory pressure also releases the fusion and restores movement that results as a natural consequence of disc injury which accelerates inflammation and natural fusion of the segment (Lamba et al, 2012). It has been reported that spinal manual therapy such as VOP may excite polymodal nociceptors and wide dynamic range neurons that stimulate the release of opioid peptides such as enkephalin and morphins (Egwu et al, 2012). These opioid peptides in the central nervous system are proposed to be a factor in the analgesic effect of VOP (Ojoawo et al, 2016). Vertical oscillatory pressure tend to produce emotions driven by the aversive primary motive system which according to Egwu et al (2012) activates the amygdala and periaquiductal gray (PAG) area which release enkephalins and endorphins to modulate pain. This is added to the widely acknowledged stress-induced analgesia activating the PAG in a similar way (Butler et al, 2009). Recently, the effect of vertical oscillatory pressure on neck pain and the cardiovascular system was studied (Ojoawo et al, 2013). The report showed that VOP effectively reduced neck pain without significantly affecting the systolic and diastolic blood pressure and heart rate in neck pain subjects (Egwu et al, 2003). In contrast, however, the systolic and diastolic blood pressure and rate pressure product increased significantly $(\mathrm{P}<0.01)$ in asymptomatic adults receiving VOP which returned to normal post treatment. Also, Egwu et al (2012) reported that the digital pressure and oscillation phases of VOP have differential effects on the analgesic potency of VOP. In their opinion, digital pressure decreases mechanical pressure generated by inflammation and collagen deposits on soft tissues in and around the intervertebral foramen to restore mobility, while decreasing electrical activity in type III and type IV fibres through normalization of blood flow and vertebra alignment. Oscillation at the pressure-pain threshold generates sufficient wide dynamic range neuron modulation of nociceptor specific neurons, down tune the amplitude of sinusoidal voltage oscillations in the dorsal root ganglion membrane to decrease muscle spasm and hyperexcitation leading to analgesia and recovery of function.

The respiratory parameters of vital capacity and respiratory rate have been widely known to increase during physical exercises which are commonly used in physical therapy (Ince et al, 2006). Previous studies have also shown that therapeutic exercises are capable of evoking cardiovascular changes such as increase myocardial oxygen demand and consumption, increased respiratory rate and depth of respiration (Bosch, 2009). It had been suggested that physical exercise can be a remedy for restrictions in physical work capacity, spinal and joint mobility, and pulmonary function (Kay et al, 2008). 
VOP is observed to be a painful procedure capable of causing anxiety which may lead to changes in respiratory mechanism (Ojoawo et al, 2016). Stress perceived by the patient during the application of a manual therapy treatment technique may account for the reported findings of sympathoexcitation and hypoalgesia immediately after its application (Egwu et al, 2012). They found that input patterns of manipulations such as VOP produce extreme emotional change in conditions involving stress or depression. This could lead to physiological changes such as increases in catecholamine and/or endorphin levels resulting in emotional modulation of pain. The stress induced hyperventilation decreases peak $\mathrm{CO} 2$ levels and increases the blood $\mathrm{pH}$ level (beyond 7.45). This contributes to elevated muscular tension and a suppression of parasympathetic activity. In a study by Bisset et al, (2015), the cervical lateral glide technique not only resulted in significant improvements in pressure pain threshold and increases in pain-free grip force, but it also produced a sympatho-excitatory response across sudomotor, cutaneous vasomotor, cardiac, and respiratory functions. Moreso, it is known that patients suffering from neck pain have reduced proprioception and disturbed motor control (McCaskey et al, 2014). Proprioception is a specialized variation of the sensory modality of touch and encompasses joint movement (kinesthesia) and joint position (joint position sense). Ojoawo et al (2016) explains the effectiveness of manipulation as a result of stimulation of the joint nociceptor and mechanoreceptor, which result in the stimulation of the golgi tendon organs and muscle spindles which breaks down the pain cycle. Mechanoreceptors are sensors that respond to changes in length, tension movement of muscles, joints and tendons. Fritz et al. (2008) stated that mechanoreceptors consist of muscle spindles which respond to changes in muscle length by bringing about a reflex contraction within muscles and Golgi tendon organs which continuously monitor tension produced by muscle contraction. According to Lalley (2013) chest wall mechanoreceptors provide respiratory motor and pre-motor neurons with important information regarding the length and force of contraction of the respiratory muscles. These signals allow changes to be made in the level of the brainstem, which lead to a compensation for changes in respiratory muscle function. Manual therapy appears to increase the respiratory function of normal individuals (Roger et al, 2007). The abrupt increase in ventilation is due to psychic stimuli from stress which are in operation even before the start of the procedure of VOP and afferent impulses from proprioceptors in muscles, tendons and joints (Lalley, 2013).

\section{Methods}

\section{Study area and population}

A total of 30 cervical spondylosis patients (16 females and 14 males) who were recruited from the Department of Physiotherapy of the Obafemi Awolowo University Teaching Hospital complex (OAUTHC), Ile Ife, Osun State, Nigeria as they were referred from a physician who diagnosed them and 30 controls (16 females and 14 males) who were apparently healthy individuals, age and sex matched candidates purposively sampled, who have not had history of neck pain for the last one year and volunteered participated in the study. Their ages are ranging from 27 to 77 years (mean $48.50 \pm 13.41$ years, 48.03 \pm 13.74 years).

\section{Research design}

The research design was pretest- posttest design.

\section{Sampling technique}

A sample of convenience was adopted for the study. Subjects who satisfied the selection criteria were recruited for the study.

\section{Ethical consideration}

The protocol for this study was approved by the Ethics and Research Committee of Obafemi Awolowo University Teaching Hospitals Complex, Ile-Ife. All the participants 
received an explanation of the procedure of the study, gave their informed consent, prior to enrollment for assessment and data collection.

\section{Data collection process}

Demographic information were obtained directly from the participants. Anthropometric characteristics were measured using standard techniques. Height was measured with a height meter (standiometer). The participant's heels, the back, and the occiput were touching the scale with the participants looking straight ahead during measurement. The height of each participant was measured to the nearest $0.1 \mathrm{~cm}$. Weight was measured with a bathroom weighing scale calibrated from $0-120 \mathrm{~kg}$ with the participant standing with shoes removed. Body weight was measured in kilograms to the nearest $1.0 \mathrm{~kg}$. Body mass index (BMI) was calculated by dividing weight in kilograms by height in meters squared $\left(\mathrm{W}(\mathrm{kg}) / \mathrm{H}\left(\mathrm{m}^{2}\right)\right.$ ).

A test-retest reliability was conducted to determine the reliability coefficient of the instruments(stop watch- timed respiratory rate, Bathroom scale- measured weights, Borg's 10- point rating scale- measured pain intensity, Spirometer- measured vital capacity, Height meter- measured standing heights). The test retest reliability coefficient of the instruments over the period of one week interval was found to be highly reliable.

The weight of the researcher was taken initially before application of vertical oscillatory pressure. Each of the subjects was requested to assume a prone lying position on a couch modified to allow normal breathing and also to monitor the vital capacity during the application of vertical oscillatory pressure. The subject was asked to lie prone with his/her forehead resting on the back of his/her hands placed on top of one another. He/She puts his/her mouth and nose in the hole at the head of the couch. The respiratory rate of the subject before the application of vertical oscillatory pressure which was determined by counting the number of lateral expansion and retraction/collapse of the thoracic wall in one minute using a stop watch. The vital capacity before the application of VOP by the researcher was measured by putting the spirometer into the subject's mouth through the hole at the head of the modified couch and instructed the subject to breathe in maximally and forcefully into the spirometer. The reading got was repeated three times and the mean average was determined (American Thoracic Society). Pain intensity of the subjects with neck pain was assessed prior to the application of VOP using a standard ten point rating scale.

The researcher stood at the head of the modified couch, placed the pads of his thumbs on the spinous process of the vertebra to be mobilized. His fingers were spread out on the sides of the subject's neck. A research assistant monitored the weight of the researcher during the application of VOP. The amount of force applied was also computed as follows: Weight of the researcher before treatment - Weight during the application of VOP. Pain intensity was assessed again immediately after spirometry in subjects with neck pain but before the end of VOP by asking the patient to rate again using a standard ten point rating scale which has been explained to the subject earlier. A research assistant measured the respiratory rate and another research assistant measured the vital capacity while the researcher was applying the VOP. The respiratory rate was determined by counting the number of lateral expansion and descent of the thoracic wall in one minute using a stop watch. Simultaneously, the vital capacity was measured by putting the spirometer into the subject's mouth and instructed the subject to breathe in maximally and forcefully into the spirometer. A wall clock was used to regulate the amount of oscillation (Ten oscillations were given to the subjects by the researcher in one minute at a rate of one oscillation every six seconds (Egwu et al, 2012). The subjects were allowed to rest for one minute in prone position on the modified couch after the application of VOP. The respiratory rate, vital capacity and pain intensity of the subjects were measured one minute after the application of VOP. The respiratory rate was determined by counting the number of lateral expansion and descent of the thoracic wall in one minute using a stop watch. The vital capacity was measured by putting the spirometer into the subject's mouth and instructed the subject to breathe in maximally and forcefully into the spirometer. The pain intensity was assessed in the subjects with neck pain using a standard ten point rating scale. 
Texila International Journal of Clinical Research

Volume 4, Issue 1, Jun 2017

The standard Borg scale was not used for the control group because they were asymptomatic of pain.

\section{Data analysis}

The data obtained were analysed using both descriptive and inferential statistics. The mean, range and standard deviation were obtained for all the quantifiable variables (age, weight, height, body mass index, respiratory rate, vital capacity and force applied). Repeated measure of ANOVA was used for the comparison of the effect of VOP on respiratory variables (respiratory rate and vital capacity) and pain intensity in the experimental and control groups. One way ANOVA was used for the comparison effect of VOP on respiratory rate and vital capacity among the experimental and control groups. LSD post- hoc test was used to probe the differences found in the ANOVA analysis.

\section{Results}

\section{Anthropometrics}

A total number of sixty participants participated in the study. The physical characteristics of subjects and the t-test results showing the differences between the experimental and control groups are shown in table 1 . It could be seen in this table that age, height, body weight and estimated body mass index were not statistically significant different between the experimental and control groups ( $p>0.05)$.

\section{Effect of VOP on respiratory rate, vital capacity and pain intensity of patients with cervical spondylosis}

The means and standard deviations of respiratory rate, vital capacity and pain intensity measured of male, female and all subjects taken before, during and after application of VOP in experimental group were shown in table 2. Comparison was made among mean respiratory variables and pain intensity of subjects with cervical spondylosis taken before, during and after application of VOP using repeated measure of ANOVA statistics in table 3. The result showed there was no statistically significant difference among respiratory rate taken before, during and after application in male subjects with cervical spondylosis $(\mathrm{p}>0.05)$. The result also showed there was statistically significant difference among respiratory rate taken before, during and after application in female subjects with cervical spondylosis $(\mathrm{p}<0.05)$. The result also showed there was no statistically significant difference among respiratory rate taken before, during and after application in all subjects with cervical spondylosis ( $p>0.05)$. The result showed there was no statistically significant difference among vital capacity taken before, during and after application in male subjects with cervical spondylosis ( $p>0.05)$. The result also showed there was no statistically significant difference among vital capacity taken before, during and after application in female subjects with cervical spondylosis ( $p>0.05$ ). The result also showed there was statistically significant difference among vital capacity taken before, during and after application in all subjects with cervical spondylosis $(\mathrm{p}<0.05)$. The result further showed there was statistically significant difference among pain intensity taken before, during and after application of VOP in the male subjects with cervical spondylosis $(\mathrm{p}<0.05)$. The result further showed there was statistically significant difference among pain intensity taken before, during and after application of VOP in the female subjects with cervical spondylosis $(p<0.05)$. The result further showed there was statistically significant difference between pain intensity taken before, during and after application of VOP in all the subjects with cervical spondylosis ( $p<0.05$ ) (Table 3). LSD post hoc statistics was done to probe the differences found within the analysis. Superscript (a, b, c) was used. For a particular variable, mode means with different superscripts are significantly $(\mathrm{P}<0.05)$ different. Mode mean with same superscript are not significantly $(\mathrm{P}>0.05)$ different. When only one contrast is significant, one of the cell means has no superscript attached. The pair of the cell means that is significant has different superscript. 
Table 1. Physical characteristics of subjects in the experimental and control groups.

\begin{tabular}{|c|c|c|c|c|c|c|c|}
\hline Variable & Sex & $\begin{array}{l}\text { Experiment } \\
\text { al Group } \\
(\mathrm{N}=30) \\
\text { Mean } \pm \text { SD }\end{array}$ & Range & $\begin{array}{l}\text { Control } \\
\text { Group } \\
(\mathbf{N}=30) \\
\text { Mean } \pm \text { SD }\end{array}$ & Range & $\begin{array}{l}t \\
\text { value }\end{array}$ & $\begin{array}{l}p \\
\text { value }\end{array}$ \\
\hline $\begin{array}{l}\text { Age } \\
\text { (years) }\end{array}$ & $\begin{array}{l}\text { Male } \\
\text { Female } \\
\text { All } \\
\text { Subjects }\end{array}$ & $\begin{array}{l}52.62 \\
\pm 10.10 \\
45.35 \pm 15.00 \\
48.50 \pm 13.41\end{array}$ & $\begin{array}{l}39-72 \\
27-77 \\
27-77\end{array}$ & $\begin{array}{l}51.54 \pm 11.51 \\
45.35 \pm 15.00 \\
48.03 \pm 13.74\end{array}$ & $\begin{array}{l}32-72 \\
27-77 \\
27-77\end{array}$ & $\begin{array}{l}0.253 \\
0.000 \\
0.130\end{array}$ & $\begin{array}{l}0.802 \\
1.000 \\
0.890\end{array}$ \\
\hline $\begin{array}{l}\text { Height } \\
\text { (meters) }\end{array}$ & $\begin{array}{l}\text { Male } \\
\text { Female } \\
\text { All } \\
\text { subjects }\end{array}$ & $\begin{array}{l}1.66 \pm 0.05 \\
1.61 \pm 0.07 \\
1.63 \pm 0.07\end{array}$ & $\begin{array}{l}1.56- \\
1.75 \\
1.54- \\
1.75 \\
1.54- \\
1.75 \\
\end{array}$ & $\begin{array}{l}1.69 \pm 0.05 \\
1.61 \pm 0.05 \\
1.65 \pm 0.07\end{array}$ & $\begin{array}{l}1.59- \\
1.79 \\
1.52- \\
1.70 \\
1.52- \\
1.79 \\
\end{array}$ & $\begin{array}{l}- \\
1.879 \\
- \\
0.253 \\
- \\
1.125 \\
\end{array}$ & $\begin{array}{l}0.072 \\
0.802 \\
0.265\end{array}$ \\
\hline $\begin{array}{l}\text { Weight } \\
\text { (Kilogra } \\
\text { m) }\end{array}$ & $\begin{array}{l}\text { Male } \\
\text { Female } \\
\text { All } \\
\text { subjects }\end{array}$ & $\begin{array}{l}66.54 \pm \pm 8.72 \\
70.06 \pm 16.64 \\
68.53 \pm 13.69\end{array}$ & $\begin{array}{l}55-84 \\
37-93 \\
37-93\end{array}$ & $\begin{array}{l}71.69 \pm 10.63 \\
66.29 \pm 13.84 \\
68.63 \pm 12.64\end{array}$ & $\begin{array}{l}56-96 \\
38-87 \\
39-93\end{array}$ & $\begin{array}{l}- \\
1.350 \\
0.717 \\
- \\
0.029\end{array}$ & $\begin{array}{l}0.189 \\
0.479 \\
0.265\end{array}$ \\
\hline $\begin{array}{l}\text { Body } \\
\text { Mass } \\
\text { Index } \\
\left(\mathrm{Kg} / \mathbf{m}^{2}\right)\end{array}$ & $\begin{array}{l}\text { Male } \\
\text { Female } \\
\text { All } \\
\text { Subjects }\end{array}$ & $\begin{array}{l}24.25 \pm 3.08 \\
27.36 \pm 7.24 \\
26.0 .2 \pm 5.94\end{array}$ & $\begin{array}{l}19.27- \\
30.12 \\
\\
15.01- \\
38.29 \\
15.01- \\
38.29\end{array}$ & $\begin{array}{l}25.53 \pm 5.37 \\
25.53 \pm 4.53\end{array}$ & $\begin{array}{l}17.48- \\
30.30 \\
\\
14.66- \\
35.56 \\
14.66 \pm 3 \\
5.56\end{array}$ & $\begin{array}{l}- \\
0.563 \\
0.838 \\
0.539\end{array}$ & $\begin{array}{l}0.408 \\
0.592\end{array}$ \\
\hline
\end{tabular}

$\mathrm{SD}=$ Standard Deviation $\mathrm{Kg} / \mathrm{m}^{2}=$ Kilogram per meter squared

* Significant, $\mathrm{P}>0.05$ (Two tailed) 
Texila International Journal of Clinical Research

Volume 4, Issue 1, Jun 2017

Table 2. Mean parameters of respiratory variables and pain intensity taken before, during and after application of vertical oscillatory pressure in experimental and control groups.

\begin{tabular}{|c|c|c|c|c|c|c|c|}
\hline \multirow[t]{2}{*}{ Variables } & \multirow[t]{2}{*}{ Sex } & \multicolumn{3}{|c|}{$\begin{array}{l}\text { Experimental Group }(\mathrm{N}=30) \\
\text { Mean } \pm \text { SD }\end{array}$} & \multicolumn{3}{|c|}{$\begin{array}{l}\text { Control Group }(\mathbf{N}=30) \\
\text { Mean } \pm \text { SD }\end{array}$} \\
\hline & & BF VOP & DUR VOP & $\begin{array}{l}\text { AFTE } \\
\text { R } \\
\text { VOP }\end{array}$ & BF VOP & DUR VOP & AFTER VOP \\
\hline \multirow[t]{2}{*}{$\begin{array}{l}\text { Respirato } \\
\text { ry Rate } \\
(\text { bpm) }\end{array}$} & $\begin{array}{l}\text { Male } \\
\text { Female }\end{array}$ & $\begin{array}{l}23.00 \pm 4.24 \\
20.00 \pm 3.32\end{array}$ & $\begin{array}{l}22.38 \pm 5.14 \\
21.47 \pm 4.19\end{array}$ & $\begin{array}{l}23.00 \pm \\
5.14 \\
20.35 \pm \\
3.57\end{array}$ & $\begin{array}{l}20.15 \pm 1.46 \\
19.05 \pm 2.01\end{array}$ & $\begin{array}{l}21.69 \pm 2.39 \\
21.11 \pm 2.89\end{array}$ & $\begin{array}{l}22.23 \pm 2.09 \\
20.94 \pm 3.15\end{array}$ \\
\hline & $\begin{array}{l}\text { All } \\
\text { Subject } \\
\text { s }\end{array}$ & $21.30 \pm 3.98$ & $21.81 \pm 4.56$ & $\begin{array}{l}21.50 \pm \\
4.45\end{array}$ & $19.53 \pm 1.85$ & $21.70 \pm 2.64$ & $21.50 \pm 2.78$ \\
\hline \multirow[t]{3}{*}{$\begin{array}{l}\text { Vital } \\
\text { Capacity }( \\
\text { ccm })\end{array}$} & Male & $\begin{array}{l}1447.46 \pm 16 \\
0.60\end{array}$ & $\begin{array}{l}1603.85 \pm 3 \\
10.17\end{array}$ & $\begin{array}{l}1513.8 \\
5 \pm 175 . \\
81\end{array}$ & $\begin{array}{l}1769.33 \pm 3 \\
17.23\end{array}$ & $\begin{array}{l}2053.84 \pm 4 \\
29.37\end{array}$ & $1930.77 \pm 221.30$ \\
\hline & Female & $\begin{array}{l}1408.41 \pm 19 \\
4.32\end{array}$ & $\begin{array}{l}1606.47 \pm 4 \\
69.21\end{array}$ & $\begin{array}{l}1474.2 \\
4 \pm 219 . \\
53\end{array}$ & $\begin{array}{l}1505.88 \pm 2 \\
48.67\end{array}$ & $\begin{array}{l}1667.65 \pm 3 \\
24.49\end{array}$ & $1591.18 \pm 280.76$ \\
\hline & $\begin{array}{l}\text { All } \\
\text { Subject } \\
\text { S }\end{array}$ & $\begin{array}{l}1425.33 \pm 17 \\
8.59\end{array}$ & $\begin{array}{l}1605.33 \pm 4 \\
01.60\end{array}$ & $\begin{array}{l}1491.4 \\
0 \pm 199 . \\
45\end{array}$ & $\begin{array}{l}1620.00 \pm 3 \\
05.58\end{array}$ & $\begin{array}{l}1835.00 \pm 4 \\
15.05\end{array}$ & $1738.33 \pm 305.04$ \\
\hline \multirow[t]{3}{*}{$\begin{array}{l}\text { Pain } \\
\text { Intensity }\end{array}$} & Male & $4.54 \pm 1.13$ & $6.15 \pm 1.41$ & $\begin{array}{l}3.62 \pm 1 \\
.12\end{array}$ & & & \\
\hline & Female & $4.47 \pm 1.33$ & $6.00 \pm 0.94$ & $\begin{array}{l}3.76 \pm 1 \\
.30\end{array}$ & & & \\
\hline & $\begin{array}{l}\text { All } \\
\text { Subject } \\
\text { s }\end{array}$ & $4.50 \pm 1.22$ & $6.07 \pm 1.14$ & $\begin{array}{l}3.70 \pm 1 \\
.21\end{array}$ & & & \\
\hline
\end{tabular}

$\mathrm{SD}=$ Standard Deviation,

$\mathrm{Bpm}=$ Beats per minute,

$\mathrm{ccm}=$ Cubic centimetre,

$\mathrm{BF}=$ Before,

DUR=During. 
Table 3. Effect of VOP on respiratory rate, vital capacity and pain intensity of patients with cervical spondylosis

\begin{tabular}{|c|c|c|c|c|c|c|}
\hline \multirow[t]{2}{*}{ VARIABLE } & \multirow[t]{2}{*}{ SEX } & \multicolumn{3}{|c|}{$\begin{array}{l}\text { Experimental Group }(\mathrm{N}=30) \\
\text { Mean } \pm \text { SD }\end{array}$} & \multirow{2}{*}{$\begin{array}{l}\text { F- } \\
\text { ratio }\end{array}$} & \multirow{2}{*}{$\begin{array}{l}\text { p- } \\
\text { Val } \\
\text { ue }\end{array}$} \\
\hline & & BF VOP & DUR VOP & $\begin{array}{l}\text { AFTER } \\
\text { VOP }\end{array}$ & & \\
\hline \multirow{3}{*}{$\begin{array}{l}\text { RESPIRAT } \\
\text { ORY RATE } \\
(\text { bpm) }\end{array}$} & MALE & $23.00 \pm 4.24^{\mathrm{a}}$ & $22.38 \pm 5.14^{\mathrm{a}}$ & $23.00 \pm 5.14^{\mathrm{a}}$ & $\begin{array}{l}0.06 \\
9\end{array}$ & $\begin{array}{l}0.93 \\
3\end{array}$ \\
\hline & $\begin{array}{l}\text { FEMAL } \\
\text { E }\end{array}$ & $20.00 \pm 3.32^{\mathrm{a}}$ & $21.47 \pm 4.19^{b}$ & $20.35 \pm 3.57^{\mathbf{b}}$ & $\begin{array}{l}4.23 \\
7\end{array}$ & $\begin{array}{l}0.02 \\
0\end{array}$ \\
\hline & $\begin{array}{l}\text { ALL } \\
\text { SUBJEC } \\
\text { TS }\end{array}$ & $21.30 \pm 3.98^{\mathrm{a}}$ & $21.81 \pm 4.56^{\mathrm{a}}$ & $21.50 \pm 4.45^{\mathrm{a}}$ & $\begin{array}{l}0.13 \\
2\end{array}$ & $\begin{array}{l}0.87 \\
7\end{array}$ \\
\hline \multirow{3}{*}{$\begin{array}{l}\text { VITAL } \\
\text { CAPACITY } \\
(\mathrm{ccm})\end{array}$} & MALE & $\begin{array}{l}1447.46 \pm 160 \\
60^{\mathrm{a}}\end{array}$ & $\begin{array}{l}1603.85 \pm 310 \\
17^{\mathrm{a}}\end{array}$ & $\begin{array}{l}1513.85 \pm 175 \\
81^{\mathrm{a}}\end{array}$ & $\begin{array}{l}1.57 \\
1\end{array}$ & $\begin{array}{l}0.22 \\
2\end{array}$ \\
\hline & $\begin{array}{l}\text { FEMAL } \\
\text { E }\end{array}$ & $\begin{array}{l}1408.41 \pm 194 . \\
32^{\mathrm{a}}\end{array}$ & $\begin{array}{l}1606.47 \pm 469 . \\
21^{\mathrm{a}}\end{array}$ & $\begin{array}{l}1474.24 \pm 219 . \\
53^{\mathrm{a}}\end{array}$ & $\begin{array}{l}1.69 \\
5 \\
\end{array}$ & $\begin{array}{l}0.19 \\
4\end{array}$ \\
\hline & $\begin{array}{l}\text { ALL } \\
\text { SUBJEC } \\
\text { TS }\end{array}$ & $\begin{array}{l}1425.33 \pm 178 \\
59^{\mathrm{a}}\end{array}$ & $\begin{array}{l}1605.33 \pm 401 \\
60^{\mathrm{b}}\end{array}$ & $\begin{array}{l}1491.40 \pm 199 \\
45^{\mathbf{b}}\end{array}$ & $\begin{array}{l}3.20 \\
3\end{array}$ & $\begin{array}{l}0.04 \\
5\end{array}$ \\
\hline \multirow[t]{3}{*}{$\begin{array}{l}\text { PAIN } \\
\text { INTENSITY }\end{array}$} & MALE & $4.54 \pm 1.13^{\mathrm{a}}$ & $6.15 \pm 1.41^{\mathrm{b}}$ & $3.62 \pm 1.12^{\mathrm{a}}$ & $\begin{array}{l}14.3 \\
08\end{array}$ & $\begin{array}{l}0.00 \\
1\end{array}$ \\
\hline & $\begin{array}{l}\text { FEMAL } \\
\text { E }\end{array}$ & $4.47 \pm 1.33^{\mathrm{a}}$ & $6.00 \pm 0.94^{\mathrm{b}}$ & $3.76 \pm 1.30^{\mathrm{a}}$ & $\begin{array}{ll}15.3 \\
75\end{array}$ & $\begin{array}{l}0.00 \\
1 \\
\end{array}$ \\
\hline & $\begin{array}{l}\text { ALL } \\
\text { SUBJEC } \\
\text { TS }\end{array}$ & $4.50 \pm 1.22^{\mathrm{a}}$ & $6.07 \pm 1.14^{\mathrm{b}}$ & $3.70 \pm 1.21^{\mathrm{c}}$ & $\begin{array}{l}30.5 \\
87\end{array}$ & $\begin{array}{l}0.00 \\
1\end{array}$ \\
\hline
\end{tabular}

Bef. $=$ Before, Dur. $=$ During, $\mathrm{SD}=$ Standard Deviation. Superscript $(\mathrm{a}, \mathrm{b}, \mathrm{c})$, For $\mathrm{a}$ particular variable, mode means with different superscripts are significantly $(\mathrm{P}<0.05)$ different. Mode mean with same superscript are not significantly $(\mathrm{P}>0.05)$ different. When only one contrast is significant, one of the cell means has no superscript attached. The pair of the cell means that is significant has different superscript.

\section{Effect of VOP on respiratory rate and vital capacity of apparently healthy controls}

Comparison was made between mean respiratory rate and vital capacity of apparently healthy control subjects taken before, during and after application of VOP using repeated measure of ANOVA statistics in table 4. The result showed there was statistically significant difference among respiratory rate taken before, during and after application in male control subjects $(\mathrm{p}<0.05)$. The result also showed there was no statistically significant difference among respiratory rate taken before, during and after application in female control subjects (p>0.05). The result also showed there was statistically significant difference among respiratory rate taken before, during and after application in all the control subjects $(\mathrm{p}<0.05)$. The result also showed there was no statistically significant difference among vital capacity taken before, during and after application in male control subjects ( $p>0.05)$. The result also showed there was no statistically significant difference among vital capacity taken before, during and after application in female control subjects ( $p>0.05$ ). The result also showed there was statistically significant difference among vital capacity taken before, during and after application in all the control subjects $(\mathrm{p}<0.05)$ (Table 4). LSD post hoc statistics was done to probe the differences found within the analysis. Superscript (a, b, c) was used. For a particular variable, mode means with different superscripts are significantly $(\mathrm{P}<0.05)$ different. Mode mean with same superscript are not significantly $(\mathrm{P}>0.05)$ different. When only one contrast 
Texila International Journal of Clinical Research

Volume 4, Issue 1, Jun 2017

is significant, one of the cell means has no superscript attached. The pair of the cell means that is significant has different superscript.

Table 4. Effect of VOP on respiratory rate and vital capacity of apparently healthy controls

\begin{tabular}{|c|c|c|c|c|c|c|}
\hline \multirow{2}{*}{$\begin{array}{l}\text { VARIABL } \\
\text { ES }\end{array}$} & \multirow[t]{2}{*}{ SEX } & \multicolumn{3}{|c|}{ Control Group $(\mathrm{N}=30)$ Mean \pm SD } & \multirow{2}{*}{$\begin{array}{l}\text { F- } \\
\text { rati } \\
\text { o }\end{array}$} & \multirow{2}{*}{$\begin{array}{l}\text { p- } \\
\text { valu } \\
\text { e }\end{array}$} \\
\hline & & BF VOP & DUR VOP & AFTER VOP & & \\
\hline \multirow[t]{3}{*}{$\begin{array}{l}\text { Respiratory } \\
\text { Rate (bpm) }\end{array}$} & MALE & $20.15 \pm 1.46^{\mathrm{a}}$ & $21.69 \pm 2.39^{\mathrm{a}}$ & $22.23 \pm 2.09^{\mathbf{b}}$ & $\begin{array}{l}3.70 \\
4\end{array}$ & $\begin{array}{l}0.03 \\
4\end{array}$ \\
\hline & FEMALE & $19.05 \pm 2.01^{\mathrm{a}}$ & $21.11 \pm 2.89^{\mathrm{a}}$ & $20.94 \pm 3.15^{\mathrm{a}}$ & $\begin{array}{l}0.72 \\
9\end{array}$ & $\begin{array}{l}0.48 \\
8\end{array}$ \\
\hline & $\begin{array}{l}\text { ALL } \\
\text { SUBJEC } \\
\text { TS }\end{array}$ & $19.53 \pm 1.85^{\mathrm{a}}$ & $21.70 \pm 2.64^{\mathrm{b}}$ & $21.50 \pm 2.78^{\mathrm{b}}$ & $\begin{array}{l}7.12 \\
4\end{array}$ & $\begin{array}{l}0.00 \\
1\end{array}$ \\
\hline \multirow{3}{*}{$\begin{array}{l}\text { Vital } \\
\text { Capacity } \\
(\mathrm{ccm})\end{array}$} & MALE & $\begin{array}{l}1769.33 \pm 317 \\
23^{\mathrm{a}}\end{array}$ & $\begin{array}{l}2053.84 \pm 429.3 \\
7^{\text {a }}\end{array}$ & $\begin{array}{l}1930.77 \pm 221.3 \\
0^{\mathrm{a}}\end{array}$ & $\begin{array}{l}2.37 \\
9\end{array}$ & $\begin{array}{l}0.10 \\
7\end{array}$ \\
\hline & FEMALE & $\begin{array}{l}1505.88 \pm 248 . \\
67^{\mathrm{a}}\end{array}$ & $\begin{array}{l}1667.65 \pm 324.4 \\
9^{\mathrm{a}}\end{array}$ & $\begin{array}{l}1591.18 \pm 280.7 \\
6^{a}\end{array}$ & $\begin{array}{l}1.35 \\
8 \\
\end{array}$ & $\begin{array}{l}0.26 \\
7 \\
\end{array}$ \\
\hline & $\begin{array}{l}\text { ALL } \\
\text { SUBJEC } \\
\text { TS } \\
\end{array}$ & $\begin{array}{l}1620.00 \pm 305 \\
58^{\mathrm{a}}\end{array}$ & $\begin{array}{l}1835.00 \pm 415.0 \\
5^{\text {b }}\end{array}$ & $\begin{array}{l}1738.33 \pm 305.0 \\
4^{\mathrm{b}}\end{array}$ & $\begin{array}{l}2.90 \\
9\end{array}$ & $\begin{array}{l}0.06 \\
0\end{array}$ \\
\hline
\end{tabular}

Bef. $=$ Before, Dur. $=$ During, $\mathrm{SD}=$ Standard Deviation. Superscript $(\mathrm{a}, \mathrm{b}, \mathrm{c})$ was used. For a particular variable, mode means with different superscripts are significantly $(\mathrm{P}<0.05)$ different. Mode mean with same superscript are not significantly $(\mathrm{P}>0.05)$ different. When only one contrast is significant, one of the cell means has no superscript attached. The pair of the cell means that is significant has different superscript.

\section{Comparison of the effect of VOP on respiratory rate and vital capacity among the experimental and control group}

Comparison was made among mean difference respiratory variables (respiratory rate and vital capacity) of the experimental and control groups taken before, during and after using one way ANOVA statistics in table 5. The result showed there was statistically significant difference on respiratory rate of male subjects in the experimental and control groups $(p<0.05)$. The result also showed there was statistically significant difference on respiratory rate of female subjects in the experimental and control groups $(p<0.05)$. The result also showed there was statistically significant difference on respiratory rate of all the subjects in the experimental and control groups $(\mathrm{p}<0.05)$. The result further showed there was no statistically significant difference on vital capacity of male subjects in the experimental and control groups ( $p>0.05$ ). The result further showed there was no statistically significant difference on vital capacity of female subjects in the experimental and control groups ( $p>$ 0.05 ). The result further showed there was no statistically significant difference on vital capacity of all the subjects in the experimental and control groups ( $p>0.05$ ). LSD post hoc statistics was done to probe the differences found within the analysis. Superscript (a, b, c) was used. For a particular variable, mode means with different superscripts are significantly $(\mathrm{P}<0.05)$ different. Mode mean with same superscript are not significantly $(\mathrm{P}>0.05)$ different. When only one contrast is significant, one of the cell means has no superscript attached. The pair of the cell means that is significant has different superscript. 
Table 5. Effect of VOP on respiratory rate and vital capacity of patients with cervical spondylosis and apparently healthy controls

\begin{tabular}{|c|c|c|c|c|c|c|c|}
\hline \multirow[t]{2}{*}{ VARIABLE } & \multirow[t]{2}{*}{ SEX } & \multicolumn{2}{|c|}{ Experimental Group } & \multicolumn{2}{|c|}{ Control Group } & \multirow{2}{*}{\begin{tabular}{|l|} 
F- \\
rati \\
o \\
\end{tabular}} & \multirow{2}{*}{$\begin{array}{l}\text { p- } \\
\text { Val } \\
\text { ue }\end{array}$} \\
\hline & & $\begin{array}{l}X \pm S D(\text { Dur } \\
\text { ing) }\end{array}$ & $\begin{array}{l}X \pm S D(A f t \\
\text { er) }\end{array}$ & $\begin{array}{l}\mathrm{X} \pm \mathrm{SD} \text { (Dur } \\
\text { ing) }\end{array}$ & $\begin{array}{l}X \pm S D \text { (Aft } \\
\text { er) }\end{array}$ & & \\
\hline \multirow{3}{*}{$\begin{array}{l}\text { RESPIRAT } \\
\text { ORY } \\
\text { RATE } \\
\text { (bpm) }\end{array}$} & MALE & $0.62 \pm 3.20^{\mathrm{a}}$ & $\begin{array}{l}0.60 \pm 2.55 \\
\mathrm{a}\end{array}$ & $1.53 \pm 2.47^{b}$ & $2.07 \pm 2.14^{\mathrm{b}}$ & \begin{tabular}{|l|}
3.0 \\
38 \\
\end{tabular} & $\begin{array}{l}0.03 \\
8 \\
\end{array}$ \\
\hline & \begin{tabular}{|l|} 
FEMAL \\
E \\
\end{tabular} & 1.4 & $\begin{array}{l}2.08 \pm 2.14 \\
\mathrm{a}\end{array}$ & $2.65 \pm 1.84^{\mathrm{b}}$ & $1.88 \pm 1.93^{\mathrm{b}}$ & \begin{tabular}{|l|}
2.9 \\
50 \\
\end{tabular} & $\begin{array}{l}0.03 \\
9 \\
\end{array}$ \\
\hline & $\begin{array}{l}\text { ALL } \\
\text { SUBJE } \\
\text { CTS } \\
\end{array}$ & $0.57 \pm 3.21^{\mathrm{a}}$ & $\begin{array}{l}0.20 \pm 2.34 \\
\text { a }\end{array}$ & $2.17 \pm 2.17^{\mathrm{b}}$ & $1.97 \pm 1.99^{c}$ & $\begin{array}{l}4.7 \\
77\end{array}$ & $\begin{array}{l}0.00 \\
4\end{array}$ \\
\hline \multirow{3}{*}{$\begin{array}{l}\text { VITAL } \\
\text { CAPACITY } \\
(\mathrm{ccm})\end{array}$} & MALE & $\begin{array}{l}156.38 \pm 21 \\
4.41^{\mathrm{a}}\end{array}$ & $\begin{array}{l}66.38 \pm 13 \\
4.07^{\mathrm{a}}\end{array}$ & $\begin{array}{l}284.62 \pm 48 \\
1.05^{\mathrm{a}}\end{array}$ & $\begin{array}{l}161.54 \pm 16 \\
6.02^{\mathrm{a}}\end{array}$ & $\begin{array}{l}1.2 \\
94 \\
\end{array}$ & $\begin{array}{l}0.28 \\
7 \\
\end{array}$ \\
\hline & $\begin{array}{l}\text { FEMAL } \\
\text { E }\end{array}$ & $\begin{array}{l}198.06 \pm 37 \\
6.40^{\mathrm{a}}\end{array}$ & $\begin{array}{l}65.82 \pm 19 \\
4.26^{\mathrm{a}} \\
\end{array}$ & $\begin{array}{l}161.76 \pm 17 \\
0.96^{\mathrm{a}}\end{array}$ & $\begin{array}{l}85.29 \pm 132 . \\
00^{\mathrm{a}}\end{array}$ & \begin{tabular}{|l|}
1.1 \\
77 \\
\end{tabular} & $\begin{array}{l}0.32 \\
6 \\
\end{array}$ \\
\hline & $\begin{array}{l}\text { ALL } \\
\text { SUBJE } \\
\text { CTS } \\
\end{array}$ & $\begin{array}{l}180.00 \pm 31 \\
2.46^{\mathrm{a}}\end{array}$ & $\begin{array}{l}66.07 \pm 16 \\
8.10^{\mathrm{a}}\end{array}$ & $\begin{array}{l}215.00 \pm 34 \\
0.17^{\mathrm{a}}\end{array}$ & $\begin{array}{l}118.33 \pm 14 \\
9.99^{\mathrm{a}}\end{array}$ & $\begin{array}{l}1.9 \\
79\end{array}$ & $\begin{array}{l}0.12 \\
1\end{array}$ \\
\hline
\end{tabular}

Superscript $(\mathrm{a}, \mathrm{b}, \mathrm{c})$ was used. For a particular variable, mode means with different superscripts are significantly $(\mathrm{P}<0.05)$ different. Mode mean with same superscript are not significantly $(\mathrm{P}>0.05)$ different. When only one contrast is significant, one of the cell means has no superscript attached. The pair of the cell means that is significant has different superscript. $\mathrm{X}=$ mean difference (between baseline and during VOP, between baseline and after VOP). Bpm=beats per minute, $\mathrm{ccm}=$ cubic centimeter.

\section{Discussion}

This study was conducted to investigate the effect of vertical oscillatory pressure on pain intensity and respiratory variables of patients with cervical spondylosis. The study determined and compared the pain intensity, respiratory rate and vital capacity during and after the application of vertical oscillatory pressure (VOP) in patients with cervical spondylosis.

The result of this study showed no statistically significant difference in respiratory rate taken before and after application of VOP in patients with cervical spondylosis $(\mathrm{P}>0.05)$. The first hypothesis, which stated that VOP will have no significant effect on respiratory rate of subjects with cervical spondylosis, was, therefore, accepted ( $p>0.05)$. This finding implies that the effect of vertical oscillatory pressure which is believed to extend beyond sudomotor and peripheral vasomotor systems to include respiratory system does not affect the respiratory rate of patients with cervical spondylosis. Hence it is a safe procedure in these patients. The outcome of this study supported the study carried out by Wall et al (2016) which stated that manual therapy applied to lower cervical and upper thoracic vertebra had no significant effect on the respiratory rate of apparently healthy subjects.

The result of this study also showed there was statistically significant difference in vital capacity taken before, during and after application of VOP in patients with cervical spondylosis $(\mathrm{p}<0.05)$. Therefore, part of the first hypothesis which stated that VOP will have no significant effect on vital capacity of subjects with cervical spondylosis was, therefore, rejected. This implies there was a significant increase in vital capacity of patients with cervical spondylosis taken after application of VOP compared with the baseline measurements. It implies that chest wall mechanoreceptors which provide respiratory motor and pre-motor neurons with important information regarding the length and force of contraction of the respiratory muscles were stimulated. These signals allow changes to be made in the level of the brainstem, which lead to a compensation for changes in respiratory muscle function and hence the increase in the vital capacity. It shows that VOP has the 
potential of improving the vital capacity or patients with cervical spondylosis. The outcome of this study is supported by a related study by Rogel M et al, 2007, who investigated the effect of combining manual therapy with exercise on respiratory functions of normal subjects were investigated. Their result showed that manual therapy had a significant effect with increases in forced vital capacity (FVC) $(P=.000$, generalized linear model (GLM)) and forced expiratory volume in 1 seconds $\left(\mathrm{FEV}_{1}\right)(P=.001, \mathrm{GLM})$. These findings are also in line with a study by Engel and Vemulpad (2007) who reported increases in FVC/FEV 1 lung function measures following nonspecific high-velocity low-amplitude manipulation of the lower cervical and thoracic spine, and the posterior articulations of the associated ribs in healthy individuals.

Furthermore, the results showed a statistically significant difference in pain intensity taken before and after application of VOP in patients with cervical spondylosis $(\mathrm{p}<0.05)$. Therefore, the second hypothesis which stated that VOP will have no significant effect on pain intensity of subjects with cervical spondylosis was also rejected. This implies there was a significant effect on pain intensity with a decrease in the pain intensity after the application of VOP compared with the baseline measurements in patients with cervical spondylosis. It shows Digital pressure (VOP) decreases mechanical pressure generated by inflammation and collagen deposits on soft tissue in and around the intervertebral foramen to restore mobility, while decreasing electrical activity in type III and type IV fibers through normalization of blood flow and vertebral alignment. Oscillation (VOP) at the pressure- pain threshold generates sufficient wide dynamic range neuron modulation of nociceptor specific neurons, downtunes the amplitude of sinusoidal voltage oscillations in the dorsal root ganglion membrane to decrease muscle spasm and hyperexcitation leading to analgesia and recovery of function. This result supports the previous works of Ojoawo et al, 2016; Gupta et al, 2008) in which VOP was observed to decrease pain intensity scores without gender or age group bias.

\section{Limitation of the study}

Some limiting factors which could have affected this study one way or the other were:

1. Some subjects were referred but declined to give their consent.

2. Also, the study could not be distributed over a large area of population.

\section{Conclusion}

It can be concluded from this study that there was a strong association between the hypoalgesic effect of VOP and the sympatho-excitatory response which cuts across the respiratory functions of patients with cervical spondylosis involving respiratory rate and vital capacity.

\section{Recommendation}

Based on the findings of the study, the following recommendations are advanced:

1. The use of vertical oscillatory pressure may be recommended as an adjunct therapeutic option for clinical reduction of pain and improvement of respiratory functions (respiratory rate and vital capacity) of patients with cervical spondylosis.

2. Additional work may be conducted to objectively assess the effect of vertical oscillatory pressure on other respiratory parameters e.g. forced expiratory volume in 1 second $\left(\mathrm{FEV}_{1}\right)$, forced vital capacity (FVC) of patients with cervical spondylosis. These will be good predictors of improvement in respiratory functions of patients with cervical spondylosis coexisting with respiratory disorders.

3. Long term follow- ups are needed for pain measures as this study only investigated effects immediately post-application of vertical oscillatory pressure. 


\section{References}

[1]. Azevedo, K.S., Luiz, R.R., Rocco, P.R.M., Conde, M.B (2012). Vital capacity and inspiratory capacity as additional parameters to evaluate bronchodilator response in asthmatic patients: a cross sectional study. BMC Pulmonary Medicine. 12: 49. Doi: 10.1186/1471-2466-12-49.

[2]. Bisset, L.M., Vicenzino, B (2015). Physiotherapy management of lateral epicondylalgia. Journal of Physiotherapy. Volume 61. Issue 4. Pages 174-181. DOI: http://dx.doi.org/10.1016/j.jphys.2015.07.015.

[3]. Bosch, A.N (2009). Exercise science and coaching: correcting common misunderstandings about endurance exercise. International Journal of Sport Science and Coaching. Volume 1. Number 1.

[4]. Briggs, A.M., Smith, A.J., Streker, L.M., Bragge, P (2009). Thoracic spine pain in the general population: prevalence, incidence and associated factors in children, adolescents and adults. A systematic review. BMC Musculoskeletal Disorders. 10. 77. Doi: 10.1186/1471-2474-10-77.

[5]. Butler, R.K., Finn, D.P (2009)' Stress-induced analgesia. Progress in Neurobiology. Volume 88. Issue 3. Pages 184-202. https://doi.org/10.1016/j.pneurobio.2009.04.003.

[6]. Corwell, B.N (2013). The emergency department evaluation, management, and treatment of back pain. Emergency Medicine Clinics of North America. Volume 28. Issue 4. Pp 811-839.

[7]. Egwu M. O., Ojeyinka A. A., Olaogun M. O. B (2007). The Effect of Vertical Oscillatory Pressure on Youths and Elderly Adult Low Back Pain intensity and lumbosacral mobility. Journal of the Japanese Physical Therapy Association; 10:1, $17-26$.

[8]. Egwu, M. O., Alabi M., Nwuga V. C. B (2003). Effect of Vertical Oscillatory Pressure on neck Pain and Some Cardiovascular variables. Physiotherapy (London), 89: 666 - 674.

[9]. Egwu, M.O., Adeoshun, I.O., Olaogun, M.O.B., Ikem, I.C., Ukponmwan, O.E (2012). Cortical electrophysiological changes during vertical oscillatory pressure therapy in patients with low back pain. Intercontinental Journal of Medicine and Medical Sciences (UK). 2: 1-7.

[10]. Fritz, S., Chaitow, L., Hymel, G.M (2008). Review of pertinent anatomy and physiology. Clinical Massage in the Health Care Setting. Volume 2008. Pp 140-195.

[11]. Gupta S, Jaiswal P, Chhabra D (2008). A comparative study between post isometric relaxation and isometric exercise in nonspecific neck pain. J ExercSciPhysiother. 4:88e94.

[12]. Henderson, A.L., Latimer, C., Millis, D.L (2013). Rehabilitation and Physical therapy for selected orthopaedic conditions in Veterinary patients. Veterinary Clinics of North America: Small Animal Practice. Volume 45. Issue 1. Pp 91-121.

[13]. Hoy, D.G., Protani, M., De, R., Bushbinder, R (2010). The epidemiology of neck pain. Best Pract Res ClinRheumatol. 24 (6). Pp 783- 792.

[14]. Ince, C., Sarpel, T., Durjun, B., Erdogan, S (2006). Effects of a Multimodal Exercise Program for People with Ankylosing Spondylitis. Physical Therapy. 86(7). Pp 924-35 .

[15]. International Association for the study of Pain (2017) in Merskey H. and Bogduck. Classification of chronic Pain, Description of Pain Syndromes and Definition of Pain Terms 2nd edn. International Association for the study of Pain (IASP) Press, Seattle, Pp. 210 - 220.

[16]. Karnath, B.M (2012). Identifying the musculoskeletal causes of neck pain. J Musculoskel Med. 29. Pp 82-86.

[17]. Kay, T., Rutherford, S., McCall, R., Voth, S., Gross, A.R., Santaguida, L (2008).Exercises for mechanical neck disorders: a Cochrane review update. Orthopaedic Symposium 2008.

[18]. Lamba, D., Rani, D., Gaur, N., Upadhyay, R., Bisht, N (2012). The effect of neural mobilization with cervical traction in cervical radiculopathy patients. Indian Journal of Physiotherapy \& Occupational Therapy. Vol. 6, No. 2. Pp 46-49.

[19]. Lalley, P.M (2013). The aging respiratory system. Pulmonary structure, function and neural control. Respiratory Physiology and Neurobiology. Volume 187. Issue 3. Pp 199-210.

[20]. McCaskey, M.A., Schuster-Amft, C., Wirth B., Suica, Z., de Bruin, E.D (2014). Effects of proprioceptive exercises on pain and function in chronic neck- and low back pain rehabilitation: a systematic literature review. BMC Musculoskeletal Disorders. 15:382. DOI: 10.1186/1471-2474-15382. 
Texila International Journal of Clinical Research

Volume 4, Issue 1, Jun 2017

[21]. Ohlendorf, D., Wanke, E.M., Filmann, N., Groneberg, D.A., Gerber, A (2017). Fit to play: posture and seating position analysis with professional musicians. A study protocol. Journal of Occupational Medicine and Toxicology. Volume 12. Issue 5. Doi: 10.1186/s12995-107-0151-2.

[22]. O’Leary, F., Hayen, A., Lockie, F., Peat, J (2015). Defining normal ranges and centiles for heart and respiratory rates in infants and children: a cross- sectional study of patients attending an Australian tertiary hospital pediatric emergency department. Arch Dis Child. 100 (8): 733- 737.

[23]. Ojoawo, A. O., Olaogun, M. O., Odejide, S. A., Badru, A. A (2013). Effect of vertical oscillatory pressure on disability of patients with chronic mechanical low back pain using Roland Morris Disability questionnaire. Tanzania Journal of Health Research. Volume.15 No.1.

[24]. Ojoawo, A.O., Olabode, A., Esan, O., Badru, A., Odejide, S., Arilewola, B (2016). Transverse oscillatory pressure in management of cervical radiculopathy: A randomised controlled study. Hong Kong Physiotherapy Journal. Volume 34. Pp 19-26.

[25]. Powers, C.M., Beneck, G.J., Hulig, K., Landel, R.F., Fredericson, M (2008). 'Effects of a single session of posterior-to-anterior spinal mobilization and press-up exercise on pain and response with lumbar spine extension in people with nonspecific low back pain', Journal of the American Physical Therapy Association, Vol.88, Pp.485-493.

[26]. Roger, M., Engel, D.C., Subramanyam, V (2007). The Effect of Combining Manual Therapy with Exercise on the Respiratory Function of Normal Individuals: A Randomized Control Trial. Journal of Manipulative and Physiological Therapeutics Volume 30, Issue 7, September. Pages 509-513.

[27]. Salisbury, C., Foster, N.E., Hopper, C., Bishop, A., Hollinghurst, S., Coast, J et al (2013). A pragmatic randomized controlled trial of the effectiveness and cost- effectiveness of 'Physio Direct' telephone assessment and advice services for Physiotherapy. Health Technol ASSess. 17 (2). Pp 1143.

[28]. Wall, B.A., Peiffer, J.J., Losco, B., Hebert, J.J (2016). The effect of manual therapy on pulmonary function in healthy adults. Scientific Reports6, Article number: 33244. Doi: $10.1038 /$ srep33244. 